\title{
Angola: Nationalist Narratives and Alternative Histories
}

\section{Introduction}

\author{
JEREMY BALL \\ Dickinson College, Carlisle, Pennsylvania \\ https://orcid.org/0000-0001-6056-9950
}

\author{
CLAUDIA GASTROW \\ University of Johannesburg \\ https://orcid.org/0000-0001-5148-1260
}

It has been over forty years since Angolan independence and yet Angolans have not had many public opportunities to reflect on the past. The end of the country's civil war was accompanied by a peace agreement that granted a blanket amnesty to all those involved in the conflict. Unlike in South Africa or Rwanda, there have been few officially enacted spaces for ordinary citizens to recount their experiences, nor legal opportunities to seek reparation. State-sanctioned narratives play down divisions among Angolan nationalists before and after independence. Public commemoration avoids seemingly 'contentious' issues such as the civil war and tends to focus on military victories over colonialism and foreign interventions. Much of this memory landscape attempts to enforce a hegemonic vision of the past that reinforces the primary position of the ruling MPLA's (Popular Movement for the Liberation of Angola) centrality as the only legitimate ruler of Angola. ${ }^{1}$ It also seeks to locate politics in officially sanctioned arenas of action. Nevertheless, there has been increasing questioning of MPLA narratives seen in everyday attempts to reclaim and rethink controversial events and leaders, and a pushing against arguments that the political is defined by parties and mass organisations. ${ }^{2}$

Examples of the reimagining of national narratives have been evident in statesanctioned events as well as grassroots actions. The most prominent example of this has perhaps been the reburial, on 1 June 2019, of Jonas Malheiro Savimbi, the former leader of UNITA (Union for the Total Liberation of Angola) during Angola's civil war, in his home village of Lopitanga in the province of Bié. Savimbi's death

1 J. Schubert, "2002, Year Zero: History as Anti-Politics in the "New Angola”, Journal of Southern African Studies, 41, 4, 2015, 1-18; J. Pearce, 'Contesting the Past in Angolan Politics', Journal of Southern African Studies, 41, 1, 2015, 103-119; A. de Grassi, 'Rethinking the 1961 Baixa de Kassanje Revolt: Towards a Relational Geo-History of Angola', Mulemba: Revista Angolana de Ciências Sociais, 5, 10, 2015, 53-133; J. Ball, "From Cabinda to Cunene": Monuments and the Construction of Angolan Nationalism since 1975, Journal of Southern African Studies, 45, 5, 2019.

2 Memory debates are, of course, not only occurring in Angola. Recent scholarship about memory and the colonies in Portugal, includes: M. P. Meneses and E. B. Sena Martins (eds), As Guerras de Libertação e os Sonhos Coloniais (Coimbra: Edições Almedina, 2013); and P. A. Oliveira and C. Castelo (eds), Cadernos de Estudos Africanos, Memórias Coloniais, 9/10, 2006. 
in February 2002 brought the country's long conflict to an abrupt end. For the last seventeen years, his body had lain in a roughly prepared grave in the town of Luena, while the victorious MPLA regime under the leadership of President José Eduardo dos Santos, carefully cultivated a narrative that portrayed him and UNITA as illegitimate political actors, almost solely responsible for Angola's bloody conflict. Political changes, however, revealed the impossibility of official narratives controlling memory and expression. UNITA's support in urban areas has ironically increased since the end of the civil war, with it winning two provincial seats in Luanda province in the 2017 election. Youth protestors proudly sang, 'primeiro os angolanos, segundo os angolanos, terceiro os angolanos ... '(first Angolans, second Angolans, third Angolans), a phrase taken from a UNITA slogan, as they mobilised against Dos Santos in 2011 (see Marques, this issue). Savimbi's funeral therefore laid bare ongoing tensions between official versions of history, the authoritarian hold over remembrance that the MPLA has historically tried to exercise, and the barely papered over alternative visions of past and future that emanate from opposition political movements, material objects and everyday memory. One obvious example of this was the government's refusal to grant Savimbi a state funeral. This was justified on the grounds that he was not a member of government or a state official at the time of his death. ${ }^{3}$ While this is technically true, it elides the fact that for many years Savimbi was considered a legitimate potential state leader by thousands of Angolans and ruled over large swathes of the country in a state-like manner. It also ignores the reasons for why he never became a member of the government - the civil war and unceasing conflict for which all sides bore at least some responsibility. Nevertheless, his burial does signal a potential shift in the official treatment of the civil war, understandings of the nation, and what and who represents it.

Beyond the political binary of UNITA and the MPLA, however, lie (and has always lain) alternative narratives and constructions of the nation and politics, which have finally found growing space for expression. A primary example of this was the sudden outbreak of pro-democracy protests among youth activists in early 2011. Protestors appropriated official spaces, occupying for instance the Largo de Independência (Independence Square) where a statue to Agostinho Neto stands, arguably forcing a public confrontation with these symbols. Equally, as this special issue shows, contestations over regional belonging, the role of the arts in nation-building and everyday organisations, such as scouts, shed light onto organisations and discussions not dominated by formalised political movements. Since the stepping down of Dos Santos in 2017, after 38 years in power, and the inauguration of João Lourenço as president, there has appeared to be a new reckoning with the past, although how much this will allow for any radical revision of nationalist narratives is yet to be seen.

This special issue seeks to contribute to both the on the ground and scholarly openings in discussions of the meaning of angolanidade (Angolanness) and nationalism in Angola by focusing on the making and unmaking of Angola's nationalist

3 M. Luamba, 'Restos Mortais de Savimbi Exumados entre Maio e Outubro', Deutsche Welle, 11 January 2019, https://www. dw.com/pt-002/restos-mortais-de-savimbi-exumados-entre-maio-e-outubro/a-47030208. 
mythologies. It does this by tracking and interrogating nationalist constructions produced through monuments, everyday politics, official statements and art. In interrogating national myths, it also seeks to understand how these official narratives are being punctured and unmade. What new versions of 'the nation' have been forged since the civil war? Where are these imaginations located? How are Angolans remaking the past? With this specific focus, this issue delves into the silences beyond the dominant narratives, investigating how alternative interpretations of the past and the future are being forged.

To understand recent Angolan history, it is important to remember that the MPLA was never the uncontested leader of the anti-colonial struggle. Its claims of sole legitimacy were always contested. ${ }^{4}$ Divisions among Angolan nationalists meant that three distinct movements based on regional, linguistic and cultural differences developed. Thus, it was a politically divided Angola that achieved independence on 11 November 1975. The MPLA, with its urban base and the aid of Cuban troops and Soviet armaments, defeated a coalition of U.S., Zairean and South African-backed rival nationalist movements: the FNLA (Front for the National Liberation of Angola) and UNITA. Thereafter, the MPLA set out to create a new independent Angolan nationalism based on the Portuguese language, the liberation struggle itself, socialism, and colonial-era borders. Seeking to downplay regional, ethnic, linguistic and racial differences, the MPLA emphasised party allegiance and the emergence of an Angolan identity born from a shared suffering under colonialism, the liberation war, the treachery of foreign forces that intervened, and the heroism of Agostinho Neto, 'the father of the nation' (see Vasco Martins and Miguel Cardina, this issue). Nevertheless, due to the confrontations that defined independence, the MPLA's narrative often found it difficult to find solid ground. The result was an official narrative that at times even fabricated information about the genesis of the anti-colonial struggle such as the nature of its involvement in the 4 February uprising in Luanda, in order to centre the MPLA at the expense of its rivals. ${ }^{5}$

The MPLA's nationalist narrative mirrored similar ones across newly independent Africa, where other leaders opted to accept colonial-era boundaries and to celebrate nationalist movements as foundational to the production of new national identities. ${ }^{6}$ Because the Angolan nation was a creation of the late nineteenth and early twentieth centuries, the MPLA, rather than challenging this imagined community, adopted it wholesale and made itself the sole arbiter of which perspectives to include and which

4 J. A. Marcum, The Angolan Revolution, Volumes 1 \& 2 (Cambridge, MASS: M.I.T. Press, 1969-1978); J. M. Mabeko-Tali, Dissidências e Poder de Estado: o MPLA Perante si Próprio (1962-1977): Ensaio de História Politica, Volumes 1 \& 2 (Luanda: Nzila, 2001); N. MacQueen, The Decolonization of Portuguese Africa (Longman, 1997); M. Bittencourt, Estamos Juntos!: O MPLA e a Luta Anticolonial (1961-1974) (Luanda: Kilombelombe, 2008); A. de Grassi, 'Rethinking the 1961 Baixa de Kassanje Revolt', Mulemba: Revista Angolana de Ciências Sociais, 5, 10, 2015, 53-133.

5 C. Messiant, 'Em Angola, Até o Passado é Imprevisível: A Experiência de uma Investigaçãos sobre o Nacionalismo Angolano e, em Particular, o MPLA: Fontes, Crítica, Necessidades Actais da Investigação', Construindo o Passado Angolano: As Fontes e a Sua Interpretação (Lisboa: Comissão Nacional para as Comemorações dos Descobrimentos Portugueses, 2000), 815; Pearce, 'Contesting the Past in Angolan Politics', 103-119; Schubert, '2002, Year Zero'; J. M. Mabeko-Tali, Dissidências e Poder de Estado.

6 For a critique of the nation-state model, see B. Davidson, The Black Man's Burden: Africa and the Curse of the Nation-State (New York: Three Rivers Press, 1992). For a broader discussion about African nationalism, see T. K. Welliver (ed), African Nationalism and Independence (New York: Garland Publishing, 1993). 
to silence in official narratives of Angolan nationalism. ${ }^{7}$ Angola's official nationalism conflated the MPLA and the Angolan nation, promoted a single official language (Portuguese), and largely ignored regional and ethno-linguistic diversity.

Despite the MPLA's attempt to entrench a hegemonic narrative of Angolan nationalism, political tensions and everyday experiences often set the limits to its aspirations. Because of the civil war (1975 - 2002), Angolans never united around a shared foundational moment and the conflict further fractured the populace. Didier Péclard observes that in the wake of its military defeat during the early years of the civil war, UNITA used 'a broad narrative of exclusion according to which UNITA stood for those who had not only been unjustly excluded from power at independence but also pushed (again) to the margins of society in much the same way as had been the case during colonial times. ${ }^{8}$ Scholars Linda Heywood, Justin Pearce, and Vasco Martins have similarly found that a unique political consciousness developed among the peoples of the central plateau (o planalto central). What is clear is that a number of competing narratives of the nation and belonging have historically coexisted despite attempts by different political groupings to gain a hold over Angolans' political imaginations.

The existence, workings and legacies of this variety of nationalisms demands an exploration for a better understanding of Angola's past, present and future. As Eric Morier-Genoud argues, there is an urgent need to revisit the subject of nationalisms and nations in Angola, Guinea-Bissau and Mozambique to enrich and verify empirically as well as theoretically what we already know of the subject.' ${ }^{9}$ During the last decade, events on the ground have reinforced the importance of this statement. Young Angolans have increasingly openly challenged state corruption and authoritarianism. Musicians such as MCK and Luaty Beirão are part of this movement demanding that the MPLA distribute Angola's oil wealth and deliver on the promises of the liberation movement. ${ }^{10}$ Feminist organisations such as Ondjango Feminista have brought women's issues to the fore. New films, such as Independência by the collective Geração 80, are opening a space for public reflections and discussions of Angola's more recent past. Even the MPLA is rethinking its history. In 2018, Viriato da Cruz, a poet and founding member of the MPLA who had died in exile in China after being driven out of the party during infighting in the 1960s, was posthumously awarded a National Prize for Culture and Arts. Equally surprising, in 2019, the state newspaper, the Jornal de Angola, ran a special issue to commemorate the 27 May attempted coup or uprising, an event whose discussion had long been suppressed and was historically

7 For a comparative case study of FRELIMO in Mozambique, see the special edition of Kronos: Southern African Histories, 39, 1, 2013 focused on Mozambique; C. Fernandes, 'History Writing and State Legitimization in Postcolonial Mozambique: The Case of the History Workshop, Centre for African Studies, 1980-1986', Kronos: Southern African Histories, 39, 2013, 131-157; M. Cahen, 'Anticolonialism \& Nationalism: Deconstructing Synonymy, Investigating Historical Processes. Note on the Heterogeneity of Former African Colonial Portuguese Areas' in E. Morier-Genoud (ed.), Sure road? Nationalisms in Angola, Guinea-Bissau and Mozambique (Leiden: Brill, 2012), 16-17.

8 D. Péclard, 'UNITA and the Moral Economy of Exclusion in Angola, 1966-1977' in E. Morier-Genoud (ed), Sure road? Nationalisms in Angola, Guinea-Bissau and Mozambique (Leiden: Brill, 2012).

9 E. Morier-Genoud (ed), Sure Road? Nationalisms in Angola, Guinea-Bissau and Mozambique (Leiden: Brill, 2012), xvi.

10 J. Krug, 'Strange Life of Lusotropicalism in Luanda: On Race, Nationality, Gender, and Sexuality in Angola' in B. Talton and Q. T. Mill (eds), Black Subjects in Africa and Its Diaspora: Race and Gender in Research and Writing (New York: Palgrave Macmillan, 2011) 109-127; L. Beirão, Sou Eu Mais Livre, Então Diário de um Preso Político Angolano (Lisboa: Tinta da China, 2016). 
mobilised as a warning against political dissent. The remaking of the nation is actively happening on the ground.

The abovementioned developments do not, however, emerge out of a vacuum. In addition to competing visions of the nation, espoused by formal political movements such as UNITA and the FNLA, emerging research has shown the existence of grassroots visions of political inclusion and nationalism that at times intersected, if often uncomfortably, with official nationalist narratives and practices. Moorman, for instance, has highlighted the production of nationalist identities in late colonial Luanda's musseque areas, that, while MPLA-aligned, were never completely captured by the party. ${ }^{11}$ These tensions partially contributed to the infamous ' 27 de Maio' (27 of May) uprising, when a group within the MPLA led by Nito Alves (Alves Bernardo Baptista), the former Minister of Interior who had increasingly mobilised the semiindependent Comissões Populares de Bairro of Luanda's musseque neighbourhoods, attempted to oust the Neto government. Voicing grievances around racial and class exclusion, Alves and his followers were accused of staging an attempted coup. Alves and other leaders were eventually executed, while those accused of being 'factionalists' were purged from party ranks, tortured and murdered over the following few years. While the culture of fear instilled by the purges may have led to the closure of open dissent within MPLA spheres of influence, the tensions around race, class, ethnicity, African identity and belonging that fed the nitistas' ideas have continued to bubble beneath the surface, meaning that, as Jon Schubert has argued, while 'identity discourses are not mobilized openly in party politics or for popular strategies.... [they] are very much part of vernacular repertoires.' ${ }^{12}$ It is these strands of discontent and grassroots assertions of angolanidade (Angolanness) which activists, opposition leaders and ordinary Angolans have often mobilised in the face of discontent with MPLA rule, and which have forced the MPLA to assess its own official histories.

The existence of these extra-MPLA assertions of belonging are also a reminder to scholars to look beyond formal political spaces for practices and assertions of national identity and belonging. As Messiant argued in her assessment of the Bicesse and Lusaka agreements, the international community, practitioners and perhaps even scholars historically failed to take seriously forms of mobilisation occurring outside of former armed movements. ${ }^{13}$ Nowadays, one could argue, the same critique could be applied to the focus on easily recognisable forms of political mobilisation such as political parties, organised protests and civil society organisations. Nevertheless, recent scholarship has shown the complex relations of contestation, belonging and exclusion that Angolans have cultivated in relation to the built environment, ${ }^{14}$ 2008).

12 J. Schubert, Working the System: A Political Ethnography of the New Angola (Ithaca and London: Cornell University Press, 2017), 83.

13 C. Messiant, 'Why did Bicesse and Lusaka fail? A Critical Analysis' in G. Meijer (ed), From Military Peace to Social Justice: The Angolan Peace Process (London: Conciliation Resources, 2004), 16-23.

C. Gastrow, 'Aesthetic Dissent: Urban Redevelopment and Political Belonging in Luanda, Angola', Antipode, 49, 2, 2017, 377-396. 
music ${ }^{15}$ and the arts. ${ }^{16}$ Equally a growing body of work on political mobilisation has explored new areas of politics such as transport ${ }^{17}$ and ethnicity, for many years an underexplored area of research for Angola. ${ }^{18}$ More work is needed on topics such as gender, race, labour, life during the socialist period and the peace movement of the 1990s.

This special edition contributes to the growing number of studies that seek to understand the various strains of Angolan nationalism and identity, picking up on the themes discussed above to explore how these have historically been understood and are currently being remade. One of the new areas of research is memory work and nationalism, especially in the face of a country which is still grappling to consolidate a shared narrative about its civil war. ${ }^{19}$ In this issue, Aharon de Grassi picks up on these themes by examining the contestation of nationalist narratives through the geography of urban Malanje. Focusing on two monuments and other significant geographies, De Grassi asks why the start of the revolt in the Baixa de Kassanje is not commemorated as a national holiday on par with 4 February. Vasco Martins and Miguel Cardina analyse the narratives (and silences) in the Memorial António Agostinho Neto (MAAN) to interrogate elite memorialisation and what they argue is the MAAN's intention to put Neto above the divisions of Angolan nationalists and the inequalities of contemporary Angola.

In the field of the arts, Susana Souza explores the work of a new generation of Angolan artists who press against the nationalist and party structures of the MPLA art world by attempting to find alternative spaces for exhibition and addressing often controversial themes. In doing this she shows how art has been mobilised to challenge dominant narratives about nationalism and identity. This question of how different art forms can jog memory and shape narrative is highlighted in the photo essays by photographer Paul Weinberg and journalist Rafael Marques de Morais. Both men use photographs taken by Weinberg during the 1992 Angolan election campaign, one which eventually resulted in a disastrous return to war, to reflect on what that moment meant for them personally in relation to the history of apartheid, civil war and authoritarian rule that shaped both countries. Weinberg positions the election as pivotal for reflecting on the changes not only in Angola, but in the region, while Marques' account is deeply personal, reflecting on the life of a young journalist and the shocking developments he witnessed in Luanda as violence ensued.

Finally, it is generally acknowledged that much research on Angolan politics has historically been Luanda-focused, often eliding a more complex story of nationalism and politics. In this special issue, many of our authors have sought to move beyond

15 G. Lázaro and O. Silva, 'Hip-hop em Angola: O Rap da Intervenção Social', Cadernos de Estudos Africanos, 31, 2016, 41-67; A. Tomás, 'Becoming Famous: Kuduro, Politics and the Performance of Social Visibility', Critical Interventions: Journal of African Art and Visual Culture, 8, 2, 2014, 261-275; M. Moorman, 'Anatomy of Kuduro: Articulating the Angolan Body Politic after the War', African Studies Review, 57, 3, 2014, 21-40.

16 D. Collier, Repainting the Walls of Lunda: Information Colonialism and Angolan Art (Minneapolis: University of Minnesota Press, 2016).

17 P. F. Neto, 'Moving Assemblies: Socio-political Mobilization in Angola's Collective Transport', Cultural Studies, 2019, DOI: $10.1080 / 09502386.2019 .1577899$.

18 V. Martins, 'Ovimbundu Identity Attributions in Post-War Angola', Journal of Southern African Studies, 41, 4, 2015: 853-867.

19 Pearce, 'Contesting the Past in Angolan Politics', 103-119; Schubert, '2002, Year Zero', 1 -18; Ball, 'From Cabinda to Cunene?. 
Luanda-based narratives, focusing on other parts of the country to provide a more wholistic understanding of how official narratives and competitors to them have taken hold across the country. Gilson Lázaro explores armed conflict on the local level in the city of Malanje during the socialist period, 1975 - 1991, when notions of citizen and soldier became blurred. Repression following 27 May 1977 had a devastating impact on Malanje. As Lázaro explains, the MPLA's efforts at constructing peace in Malanje city after the civil war focused on public silence about the civil war and wiping out marks of war on the built environment. Jessica Auerbach, conducting research in Benguela, focuses on the Angola scouting movement, one of the largest associations in Angola not formally associated with the ruling party, but, as with almost all organisations in the country, grappling with the quotidian effects and experiences of MPLA rule. Through investigating discussions over naming and leaders' battles with their relationships to the ruling party, Auerbach investigates how movements such as the scouts both reproduce but also open potential gaps within existing narratives and political relationships. Shana Melnysyn's article explores the long-term ramifications of the 1902 Mbailundu Revolt against the Portuguese. Using archival documents as well as contemporary ethnographic fieldwork in the Mbailundu area, she shows how the revolt has long shaped political identity and nationalist narratives not only in the Mbailundu area, but at a national level as arguments about race, African identity and geographic and linguistic belonging continued to reference the significance of Mbailundu.

We had hoped to include a book review by noted Angolan scholar Paulo Faria, but the completion of the review was made difficult by Faria's firing from his position at Agostinho Neto University. This state-sanctioned silencing of an academic critic of the government illustrates one of the many challenges facing scholars who conduct research in Angola, especially Angolan scholars themselves, who have historically been subject to more pervasive pressures in relation to livelihoods and academic freedoms. In spite of these constraints, we are seeing an increasing output from both foreign and Angolan scholars, which is enriching Angolan historiography and deepening our understanding of Angola's past, present and future. ${ }^{20}$ This special issue is a small contribution then to what we hope will be a quickly growing discussion, not only among scholars but among Angolans outside of the academy.

20 In addition to work by Angolan scholars already cited in this issue, see work by António Tomás, Maria Conceição Neto, Sylvia Croese, Paulo Inglês, Nelson Pestana, Cesaltina Abreu, Claudio Tomás and Albano Troco. 